\title{
INSTITUTIONS AND DYNAMIC CAPABILITIES: THEORETICAL INSIGHTS AND RESEARCH AGENDA FOR STRATEGIC ENTREPRENEURSHIP
}

\section{Introduction}

Institutional approach (IA) and dynamic capabilities approach (DCA) have become popular lines of theorizing in management research (Peng et al., 2009; Teece, 2014), each offering valuable insights. Each approach discretely offers rather solid explanations to firm structure, behavior, and performance (Peng et al., 2009; Teece, 2007). However, they fall short of fully reflecting the multifaceted nature of management and strategy phenomena. For example, DCA views competitive advantage as a function of dynamic capabilities (DCs) especially in dynamic environments (Teece, 2007), but often overlooks the circumstances that DCs are conditioned and bounded (Barreto, 2010). Conventional theorization in IA that are often followed by mainstream empirical research posits that institutions provide meaning, structure, and template to social behavior and shape how firms behave (DiMaggio \& Powell, 1983; Hasselbladh \& Kallinikos, 2000; Meyer \& Rowan, 1977; Peng \& Khoury, 2008). However, it underplays capabilities that enable agency for creating disequilibrium and transforming business ecosystems (Teece, 2014). Researchers typically choose one approach over the other (Wright et al., 2005), resulting in fragmented insights and incomplete explanations. Even in cases of paired adoption (e.g., Wu, 2013), they often treat the two approaches independently without an involved interaction in their frameworks.

In the strategy and entrepreneurship literature, IA and DCA remain relatively engulfed, and both of them fall short of offering a fuller understanding of strategic entrepreneurship as a holistic capabilitydriven phenomenon embedded in its context (Lessard, Teece, \& Leih, 2016). These two approaches inadvertently feed the enduring structure vs. agency debate (Heugens \& Lander, 2009). Unwarranted negligence of the interplay between institutions and DCs could lead to incomplete and even inconsistent explanations (Barreto, 2010; Heugens \& Lander, 2009). 
Earlier researchers have been on a pursuit for theories to facilitate the study of strategic entrepreneurship (Alvarez, Audretsch, \& Link, 2016), and acknowledged the benefits of bridging different perspectives in doing so (Welter, Mauer, \& Wuebker, 2016). Therefore, our study is an attempt to answer this call. The central yet overlooked void in the literature is the analysis of these two approaches jointly to bridge the divide between them for their fruitful application in strategic entrepreneurship. How DCs as a key entrepreneurial attribute co-evolve with institutions as contexts that entrepreneurs populate and what underlies the interaction between them are still largely unknown (Lawrence, Suddaby, \& Leca, 2011). The need for a synthesized application of IA and DCA is highlighted by the complementary perspectives these two theoretical approaches offer to strategic entrepreneurship. Their synthesized application can help advance strategic entrepreneurship from its disparate and rather incoherent state (Burg \& Romme, 2014; Kiss, Danis, \& Cavusgil, 2011) and address the relevant phenomena more realistically and inclusively.

The purpose of this study is to provide a ground for a synthesis of institutional and dynamic capabilities approaches and develop a foundational research agenda on issues related to strategic entrepreneurship that could better be explained by such synthesis. This study lays the ground for a synthesized adoption of the two approaches for management research. In doing so, our paper takes insights from both neo-institutional theory and new institutional economics strands of IA in context of strategic entrepreneurship, as researchers focusing on IA have been influenced by debate between these complementary strands and followed insights from both strands in their theorization and empirical testing (e.g., Peng \& Khoury, 2008; Peng et al., 2009).

Our paper contributes to theory by a) developing an understanding of the interplay between institutions and DCs; b) bridging the divide between IA and DCA that follow different theoretical paradigms, have different foci, and are underlined by different sets of assumptions; and c) developing a research agenda for strategic entrepreneurship linked to better understanding of issues like agency, 
behavior, performance, and structure in context of strategic entrepreneurship. Although the two focal approaches are distinct, they are inextricably intertwined, and they have the potential to inform each other. While IA can explain how DCs are conditioned within and by institutions, DCA can explain enabling elements of socioeconomic entities actively engaging with institutions. Viewed together, their explanations of relevant issues are complementary. Thus, insights gained through the synthesized adoption of IA and DCA are expected to lead to rich, and generative theorizing enhancing understanding of strategic entrepreneurship phenomenon.

\section{Theoretical background}

The foci of strategic entrepreneurship are wide-ranging and diverse, drawing on research from multiple disciplines such as economics and sociology, together with research fields in management including organizational behavior and organization theory (Hitt et al., 2011). Simply referring to entrepreneurial activities with a strategic approach, the strategic entrepreneurship phenomenon is naturally theorized and examined at the intersection of strategic management and entrepreneurship and informed by theories adopted in these fields (Alvarez et al., 2016).

There are strong, intricate, and multifaceted connections between entrepreneurship as a research field and IA and DCA as theoretical approaches as inputs, processes, and outcomes of strategic entrepreneurship involve DCs and institutions (Hitt et al., 2011). IA and DCA are found to be two of the important lines of theorizing entrepreneurship research follows (Kiss et al., 2011). Actions are a manifestation of capabilities, and enterprises are a collection of capabilities. Thus, DCs are pivotal in underlying and defining entrepreneurial actions (Teece, 2014). At the same time, entrepreneurial and strategic behaviors are embedded in and shaped by the context in which they occur (Schriber, 2016; Welter \& Smallbone, 2011). The instrumental relevance of IA for strategic entrepreneurship resides in IA being one of the strongest theoretical approaches in explaining external (contextual) influences on socioeconomic behavior (Hoskisson et al., 2013; Peng et al., 2009). Accordingly, both approaches 
explain important influences on firm behavior and outcomes (Peng et al., 2009; Teece, 2007) and comprise important place for strategic entrepreneurship decisions and can be utilized for explaining various issues and questions within this domain.

In this section, we briefly explain the core premises of IA and DCA and the core concepts examined via these approaches i.e., institutions and DCs respectively. Then, we include the relevance of IA and DCA for strategic entrepreneurship research. Both theoretical approaches have generated substantial literature, and these approaches are not always consistent internally with respect to definitions of constructs, behavioral assumptions, and even the units of analysis. We offer a concisely stated base of the two approaches for their synthesis by drawing on the mainstream body of work in each approach rather than providing an exhaustive review of these approaches and accounting for the divergences in each approach.

\subsection{Institutions and limitations of institutional approach}

Institutions are taken-for-granted, culturally-embedded "rules of the game", which constrain, shape, and enable social and economic activity (DiMaggio \& Powell, 1983; North, 1990). They are the sum of a consistent and frequent pattern of social behaviors that majority performs. They are, in a way socially constructed "reality" of life, as human existence takes place in a context of order, direction, stability (Berger \& Luckmann, 1967). Institutions provide order to social and economic life (Metcalfe, 2001), and diffuse their influence through coercive, normative and mimetic mechanisms (DiMaggio \& Powell, 1983). Thus, the concept of institutions is used to understand how and why firms and other socio-economic entities attend, and attach meaning, to some elements of their institutional fields (Suddaby, 2010). Institutional theorists suggest that values, norms, and organizational templates often exist outside of firms but influence the way in which firms are structured and managed (Meyer \& Rowan, 1977). Institutions constitute the ground that both underpins and shapes (controls, constrains, and structures) entrepreneurship. They help account for the role of external environment in 
entrepreneurial behavior (Welter \& Smallbone, 2011), leading to a greater understanding of entrepreneurship phenomena in the context in which it occurs.

IA has two major strands, namely "new institutional economics (NIE)" and sociology-oriented "neo-institutional theory". These strands share similar views of institutions as socially constructed rules and behavioral systems that are accepted by the majority (Berger \& Luckmann, 1967; DiMaggio \& Powell, 1983; North, 1990). Likewise, central assumptions and the core tenets of these strands of IA are similar or comparable. However, these two strands have produced somewhat divergent definitions of some shared constructs and often focused on different units of analysis over time. In particular, while NIE has tended to focus on macro-level forces that influence economic decision-making and behavior (Acemoglu et al., 2003; Boschma \& Capone, 2015; North, 1990), neo-institutional theory has often focused on social and organizational fields as domains of institutions (DiMaggio \& Powell, 1983; Hasselbladh \& Kallinikos, 2000; Scott, 2001). Still, they offer complementary insights into the subject matter of this study, because macro-level institutions and organizational fields are reflected in each other's domain. Researchers have referred to using insights from both strands as being expected due to multidisciplinary nature of strategy research (Peng \& Khoury, 2008; Peng et al., 2009). In the current paper, we use insights from neo-institutional theory, NIE, and institutional entrepreneurship, when synthesizing IA and DCA to make best and holistic use of their body of knowledge across research domains to advance the understanding of strategic entrepreneurship.

IA and its economics and sociology-rooted strands have evolved further over the last decades (e.g., Seo \& Creed, 2002) and increasingly recognized the role of agency and institutional entrepreneurship in shaping institutions (Garud, Hardy, \& Maguire, 2007; Greenwood \& Suddaby, 2006; Kiss et al., 2011). However, most empirical applications of IA in business fields adhere to the dominant view of IA that emphasizes the conventional understanding (i.e., an understanding and empirical applications that follow widely accepted assumptions and arguments sown by early seminal 
works of influential institutional theorists) of institutions (Li et al., 2010), which we primarily follow when discussing the core tenets of IA. In turn, particularly conventional theorization in IA has limitations in explaining management issues (Pernkopf-Konhäusner, 2014; Suddaby, 2010). Seo and Creed (2002) illustrate the innate paradoxes of conventional IA. They explain how seeking legitimacy often undermines efficiency and creativity; adaptation to institutional demands frequently hinders adaptability to other changing requirements; and isomorphism conflicts with divergent interests of endogenous and exogenous actors (Seo \& Creed, 2002). Conventional streams of IA have understudied the issues of how socioeconomic actors proactively engage with institutional complexity (PernkopfKonhäusner, 2014), how situated forms of organizing are linked with wider instrumental beliefs and practices (Hasselbladh \& Kallinikos, 2000), how institutional differences across various contexts are explained, and what role diverse stakeholders within and across institutional systems play (Wood, Dibben, \& Ogden, 2014).

IA has inherently adopted a conformist perspective on socioeconomic behavior, and entrepreneurial approaches to relevant phenomena have until recently been muted in the institutional line of theorizing (Willmott, 2014). Conventional IA explains the persistence and homogeneity of phenomena; assumes equilibrium, similarity, and legitimacy imperative for survival; and downplays actorhood, leadership, learning, and capabilities (Kostova, Roth, \& Dacin, 2008; PernkopfKonhäusner, 2014; Seo \& Creed, 2002; Teece, 2014). Based on these limitations, strategic entrepreneurship could be confined into a specified framework under the strong presence and tight influence of institutions due to their regulative pressures and normative requirements in seeking order and reality construction. As, reality construction seeks equilibrium and order (Berger \& Luckmann, 1967), increased degree of institutionalization is associated with decreased tolerance to disruptive forces. These limitations are most relevant caveats of IA that could be remedied partly by accounting 
for DCs. Consequently, institutions and context can offer an only partial explanation to entrepreneurial behavior and performance that can be complemented via inclusion of DCs.

As mentioned earlier, IA has different facets, and one of the recent ones termed as institutional entrepreneurship has addressed some limitations of IA to an extent. Institutional theorists have referred to institutional entrepreneurs as being individuals or organizations that can create, maintain, and disrupt institutions (Lawrence \& Suddaby, 2006; McKague, 2011). It is logical to expect that such institutional entrepreneurs have unique resources or capabilities that create such an influence. However, so far institutional entrepreneurship literature has not directly linked DCs to these influences in the context of strategic entrepreneurship, as most earlier works have focused on large international or multinational organizations (e.g., Faulconbridge \& Muzio, 2015; McKague, 2011; Regnér \& Edman, 2014). Therefore, we attempt to bridge this gap by specifically focusing on strategic entrepreneurship and linking DCs with institutions.

\subsection{Dynamic capabilities and limitations of dynamic capabilities approach}

Dynamic capabilities (DCs) refer to the firm's ability to integrate, build, and reconfigure internal and external competences to address rapidly changing environments (Teece, Pisano, \& Shuen, 1997). DCs enable firms to create, deploy, and protect intangible assets (Teece, 2007). DCs are unique in a way that they are the capabilities that change capabilities (Teece, 2014; Winter, 2003). They rest on firm processes that can entrepreneurially alter current positions, leading to new positions and paths to make the best use of their strategic assets (Eriksson, 2014; Helfat \& Peteraf, 2015).

The very essence of entrepreneurial behavior, which seeks, creates, and leverages opportunity, creates value, and employs innovation, entails application and utilization of DCs (Teece, 2014). DCs are essential to explicating entrepreneurship, the nature and essence of enterprises, competitive advantage, and differentiation (Teece, 2014). DCs represent a considerable share of endogenous factors that define and empower entrepreneurship. In fact, Teece (2007) views entrepreneurship primarily as 
a function of DCs. Thus, a spin-off from resource-based theory (Eisenhardt \& Martin, 2000), DCA explains the underlying features and behavioral microfoundations of strategic entrepreneurship and entrepreneurial value creation (Teece, 2014).

Like IA, DCA is not free of limitations in its explanation of issues in management generally and strategic entrepreneurship specifically. First, recent studies warn scholars against the possibility of DCA becoming a "big tent" for management research and inflating impact of DCs (Barreto, 2010). Second, there is a growing concern on whether the DCs concept could be explained independently of variables it predicts (Arend \& Bromiley, 2009; Barreto, 2010). Furthermore, it has been argued that DCA lacks a coherent theoretical foundation; finds weak and inconsistent empirical support; and offers unclear practical implications for managerial and entrepreneurial activity (Arend \& Bromiley, 2009). Likewise, Vogel and Güttel (2013) conclude that DCA lacks consensual concepts that allow comparisons of empirical studies and advance the theoretical understanding of DCs.

Particularly with regard to strategy and entrepreneurship, DCs have often been conceptualized and studied without direct attention to (institutional) environments that define and shape origins, underlying nature, and mechanisms of DCs and influence their function and value (Dunning \& Lundan, 2010; Lessard et al., 2016). For example, DCA explains how firms sustain superior performance in a rapidly changing industry via continuous proactive and reactive change and entrepreneurial activities (Arend \& Bromiley, 2009; Teece, 2007). However, DCA has paid only recent and insufficient attention to the role of entrepreneurs and managers in the environment (Augier \& Teece, 2008; Teece, 2014). DCA often fails to account for the variations within environmental elements such as institutions and base its position on the assumption on relatively homogenous environmental characteristics (Teece, 2009). This notion is highlighted in mainstream theorization in DCA that suggests DCs are primarily relevant in an open economy with rapid innovation (Teece, 2007). This position underplays the varieties and thus the role of institutions and other environmental forces such as industry, culture, and 
socioeconomic factors in shaping firm behavior and fails to offer comprehensive, coherent, and contingent insights into strategic entrepreneurship research. Likewise, the nature of the relationship between entrepreneurship and DCA remains an unresolved issue (Arend \& Bromiley, 2009), potentially due to the incompleteness of the approach.

\section{Comparing and contrasting institutional and dynamic capabilities approaches}

In this section, we briefly analyze IA and DCA in relation to each other and reveal their differences and similarities that are evolving and signifying a potential correspondence between the two approaches. The identification of differences and commonalities between these approaches reveals that both approaches have different yet complementary premises and that two approaches can be integrated to arrive a rich and insightful explanation of relevant issues in management.

\subsection{Differences between institutional and dynamic capabilities approaches}

There are several differences between IA and DCA as depicted in Table 1. Starting with their core premises, IA's conventional core premise is that institutions provide meaning and structure to socioeconomic behavior and cognition (Lawrence et al., 2011). The cues that inform decisions and actions emerge from the relevant institutions, giving purpose, predictability, and meaning for embedded decision-makers (Garud et al., 2007). DCA's core premise is that DCs can be a source of competitive advantage (Teece, 2007, 2014) by commanding the firm's resource base and leveraging it for achieving evolutionary fitness (Katkalo, Pitelis, \& Teece, 2010). Likewise, while research following IA focuses primarily on processes, discourses, and the meaning of institutions' influence on firm behavior and structure and various responses by firms, research following DCA focuses primarily on various DCs and performance-related outcomes.

\section{Insert Table 1 here}

Furthermore, research following IA seeks to explain why and how firms adopt processes and structures for their meaning (Suddaby, 2010), while DCA focuses on their productive value when 
seeking to answer the same questions. Decision-makers rely on institutional cognitive templates and norms to make sense of and engage with the environment as well as to construct the realities that guide their behavior (Berger \& Luckmann, 1967). Yet, the key role or function of DCs is argued to be effectively transforming inputs into desired outputs primarily for the self-interest (Katkalo et al., 2010).

Whereas the expected function of the core concept of IA (i.e., institutions) is to drive convergence, the typically expected function of the core concept of DCA (i.e., DCs) is to enable differentiation. In other words, though the key question of research following DCA is "Why do firms differ?", the key question of IA tradition is "What makes organizations so similar?" (Peng et al., 2009). Conventional IA suggests that institutional influences lead to isomorphism and ensuing convergence or similarity among socioeconomic actors (Daniels, Johnson, \& de Chernatony, 2002; DiMaggio \& Powell, 1983; Oliver, 1997). The very concept of "institutionalization" denotes a convergence in actors' belief and behaviors over time. Contrarily, DCA argues that, partly due to pressures by the competitive environment that encourage divergence (Daniels et al., 2002), successful firms differentiate from their competition via DCs (Teece, 2007). Thus, IA argues that firms adapting to institutional demands are more likely to have higher survival possibilities through legitimacy (Scott, 2001); and DCA argues that firms achieve competitive advantage through value creation and relative differentiation (Katkalo et al., 2010).

DCA applies particularly to external environments with a rapid pace of change and argues that firms respond to environmental change by changing their behavior and structure rapidly through DCs (Teece, 2009), highlighting DCs as agency enablers. Strategic entrepreneurship especially implies simple structure, flexible operations, quick decision-making process, and lower formalization of processes (Baker \& Nelson, 2005; Hitt et al., 2011; Lumpkin \& Dess, 1996). Therefore, DCs of strategic entrepreneurs can be expected to be relatively easily renewable and adjustable in new 
institutional contexts. Despite being ordered and coordinated, institutions change too (Berger \& Luckmann, 1967; Metcalfe, 2001). However, many institutional theorists view institutional change as gradual, because particularly normative and cognitive institutions are inert entities (DiMaggio \& Powell, 1983; Scott, 2001), highlighting institutions as structure. Institutions, rather than their microfoundational constituents such as individual norms, take considerable time to change, due to inertia stemming from their path-dependent and relatively complex nature (Pihkala, Harmaakorpi, \& Pekkarinen, 2007).

Furthermore, DCA applies to managerial decision-making on a systematic and deliberate basis as evidenced in their systematic configuration, deployment and leverage of DCs as a part of their competitive strategy (Teece, 2009). Nonetheless, IA points out that, as all human activity is subject to habitualization (Berger \& Luckmann, 1967), managers make choices on a habitual and instinctive basis. Such basis is bounded by managers' social judgment, shared cognition, institutional pressure, and historical limitations (Ahuja \& Yayavaram, 2011; Katkalo et al., 2010; Oliver, 1997) and shaped by their symbolic environment and meaning they attribute to such environments (Suddaby, 2010).

\subsection{Commonalities between institutional and dynamic capabilities approaches}

Table 2 exhibits key commonalities between IA and DCA. When it comes to their commonalities, some of the views of both approaches on the enterprise and relations with external actors are quite similar. Both IA and DCA recognize the importance of interconnectedness and relatedness to other actors and relevant stakeholders (Oliver, 1997; Teece, 2009). IA view enterprises as embedded in their institutional contexts (Garud et al., 2007) and dependent on institutionalized "scripts" operating in their environments (Willmott, 2014). IA also acknowledges that working relationships with internal and external institutions are pivotal to obtain legitimacy and institutional capital and ultimately to survive (Oliver, 1997). Likewise, DCA acknowledges connections and relationships with other business actors to have access to necessary yet not owned resources and learning opportunities and be able to 
collaborate and share when necessary and recognizes that survival depends on evolutionary fitness to environmental requirements (Teece, 2009).

\section{Insert Table 2 here}

Second, it is acknowledged that mindful venturing lays the ground for generation and development of both DCs and institutions (Cantwell, Dunning, \& Lundan, 2009; Dunning \& Lundan, 2010). Although established institutions curb experimentation and exploration, formation phase within the lifespan of institutions involve entrepreneurial and explorative activities (Garud et al., 2007), just as in the case of DCs (Teece, 2007, 2009).

The last commonality between IA and DCA relates to the environment. In this study, environment denotes any entity or factor external to the focal actor. It is not confined to institutional environment and includes economic, socio-political, cultural, and market environment including competitors, suppliers, and customers. The external environment is becoming increasingly dynamic (Lessard et al., 2016; Teece et al., 1997), and unlike the early new institutionalism has suggested so, recent theorization in IA views the environment as more dynamic and diverse (Peng et al., 2009; Scott, 2008). Both approaches are accordingly converging in terms of their views on firms' relationship with the environment. Teece (2007) suggests that the enterprise and its environment often co-evolve. Similarly, IA has rectified the conventional view of its roots as institutional environment being fixed context only imposing requirements and constraints (Ahuja \& Yayavaram, 2011). Over the years, a new emphasis has emerged in institutional studies on understanding the role of actors in affecting, transforming, eroding, and maintaining institutions (Lawrence \& Suddaby, 2006).

\subsection{The value of synthesizing the two approaches}

The essence of promoting synthesis of the two approaches stems from the argument that assuming a rigid and binary choice between conformance- and performance-enhancing templates for firms might be ill-advised (Heugens \& Lander, 2009). Managers are unlikely to select templates merely on either 
account of their social acceptability or profit-seeking behavior (Heugens \& Lander, 2009). Likewise, strategic entrepreneurship phenomena require a holistic perspective that is a product of synthesizing fragmented lines of theorization (Burg \& Romme, 2014). Social mechanisms, contextual conditions, and outcome patterns of strategic entrepreneurship involve multiple perspectives that account for underlying mechanisms of both agency and structure.

DCA argues for developing, configuring, deploying, and utilizing capabilities in response to shifts in business environments (Teece et al., 1997). It is intuitive but at times overlooked that DCs are not standalone entities and are contingent upon the environment beyond the actors possessing or having access to them. Thus, institutions and DCs are irreducible to each other and can be better understood through the synthesis the theoretical approaches that examine these core concepts. Synthesizing IA and DCA expand management's involvement to respond to institutional forces and manage DCs while accounting for institutions and entities constituting them (e.g., Phillips \& Tracey, 2007).

Benefits of synthesizing IA and DCA for relevant issues are several. First, such synthesis allows the culmination of IA's and DCA's complementarities on relevant issues. Second, it explains firm heterogeneity and competitive advantage that incorporate the institutional boundary conditions of DCs (Oliver, 1997). Third, the synthesis of IA and DCA can explain issues in volatile and uncertain contexts that characterize the globe as a more realistic, interactive, inclusive, and dynamic framework that incorporates complementary approaches. Fourth, DCA can enable the incorporation of further reflexive appreciation of agency into IA, while IA can foster credentials of DCA by accounting for the boundaries and conditioning of DCs. The synthesis can pull both approaches closer to better and more insightful depiction of reality and considerably increases their explanatory power.

\section{Toward a synthesis of institutional and dynamic capabilities approaches}

There is a recursive and dialectical interaction between agency and institutions (Lawrence et al., 2011). Institutions, firms, and firms' DCs co-exist and co-evolve (Augier \& Teece, 2008; Cantwell et al., 
2009). Institutions subtly or overtly set the 'rules of the game' (Dunning \& Lundan, 2010) and help explain how and why some firms prioritize meaning and symbolic templates, while DCs explain how firms can differentiate. Institutions define a frame with semi-flexible boundaries in which firms can enjoy pursuing their objectives via DCs that they develop and exploit. Nonetheless, institutions are enacted and constructed by individuals and groups. Enterprises having superior DCs not only adapt to institutional and business environments, but also play a key role in shaping them, i.e., alternating their frame, via disruptive innovation and collaboration with other enterprises, entities, and institutions (Augier \& Teece, 2008; Teece, 2007). This argument is also endorsed by Durand (2012, p. 298) in his discussion of institutions in relation to firms:

"(Firms and other organizations) fashion and embody institutions, are bounded and emancipated by institutions, work to maintain and erode institutions, perform institutional functions and convey institutional logics."

In short, DCs and institutions feed each other and simultaneously explain firm behavior via two contrasting forces -one pushing toward convergence, and the other toward divergence. Thus, both institutions and DCs are needed to be incorporated into each other's analysis to arrive a richer understanding of the other as illustrated by the following arguments.

\subsection{Institutions influence dynamic capabilities}

We first apply the central argument that institutions intricately influence and configure the way in which firms are structured, managed, behave, and perform (Meyer \& Rowan, 1977; Peng et al., 2009) on DCs. Drawing on the core premises of the mainstream research on institutions (DiMaggio \& Powell, 1983; Meyer \& Rowan, 1977; North, 1990; Scott, 2001), we argue that institutions influence DCs in two major ways.

Firstly, institutions can be considered an essential constituent element of DCs (Dunning \& Lundan, 2010). DCs' certain attributes could, in one way or another, be shaped by institutions they are embedded in as institutions can play an instrumental role in constituting and shaping the 
microfoundations of DCs. Therefore, earlier studies have referred to variance in DCs of firms as well as subsidiaries of multinational corporations, operating in different institutional contexts (Dixon, Meyer, \& Day, 2014; Michailova \& Zhan, 2015). Cognitive and procedural microfoundations are important pillars of DCs (Helfat \& Peteraf, 2015; Teece, 2007). Institutional forces can play an important role in constituting and shaping the microfoundations of DCs, due to their influential role in shaping managerial cognition, value systems, and processes through organizational patterns, models, and schemes (Hasselbladh \& Kallinikos, 2000; Scott, 2001). They could function as a mold in which DCs grow and are shaped by. They can undergird sensing, seizing, and transforming activities through regulative, normative, and cognitive frameworks they provide for entrepreneurial action. Distinct entrepreneurial skills, processes, procedures, organizational structures, decision rules, and disciplines as pivotal microfoundations of DCs (Teece, 2007) are all engrained in and conditioned by institutions. For example, human capital formed by distinct entrepreneurial skills and managerial processes cannot be explained independent of the institutional context in which it is built, as it is considerably different in emerging markets than in developed markets (Algieri, 2006). Likewise, institutions are a key driving force underpinning the content and pattern of the exploration and exploitation of resources and capabilities (Dunning \& Lundan, 2010). Furthermore, it takes a different set of DCs to operate in resource-constraint institutional environments and rely on bricolage (Baker \& Nelson, 2005) than in resource-munificent and institutionally conducive settings (Wu, 2013). These examples illustrate that institutions provide the foundational means by which firms build and link their tangible and intangible resources that are intertwined with their DCs.

Institutions can also play a pivotal role in reducing the uncertainty that could surround activities involving the inception and development of DCs (Beckert, 1999) and influence the search for new ways of dealing with uncertainty (Dunning \& Lundan, 2010). Likewise, some institutional fields impose firms to focus on developing upstream (operational) capabilities rather than downstream 
(strategic) capabilities (Hoskisson et al., 2013). Institutions supply the means by which firms build and link their resources through their strategies (Gammeltoft, Barnard, \& Madhok, 2010). For example, both the creation and effective use of firm R\&D fundamentally depends on institutional infrastructure (Dunning \& Lundan, 2010). Moreover, in emerging or developing economies, a weak institutional environment can also have some positive influences on the development of DCs, especially for strategic entrepreneurship. Institutional uncertainty has been found to result in offering entrepreneurs more room for discretion and flexibility, resulting in the development of DCs particular to emerging economy context (Lu et al., 2009). In short, differences in local institutions play an important role in shaping the evolution of competitive DCs.

Second, beyond the initial stages of the evolution of DCs, institutions constitute underlying (inhibitive, facilitative, or otherwise) mechanisms and processes for deploying, manifesting, utilizing, and valuing DCs. In particular, institutions may have constraining or jeopardizing influence on DCs and their function. The deployment and utilization of DCs can be hampered in restrictive institutions (Acemoglu et al., 2003). For example, some sensing, seizing, and reconfiguring activities, given their unorthodox and innovative nature, can be perceived as deviations from norms in contexts where social institutions pose greater monitoring and sanctioning constraints (Taras, Kirkman, \& Steel, 2010). Thus, firms cannot be able to freely practice entrepreneurial activities in some institutional settings. Furthermore, restrictive institutions can obscure capability transfer, which could be pivotal to achieve competitive advantage (Teece, 2014), across institutional settings (Dunning \& Lundan, 2010). Likewise, weak institutions, even if they do not impose restrictions, face higher volatility that hampers firms' entrepreneurial capabilities and performance (Acemoglu et al., 2003).

Exploring the interface between institutions and DCs in emerging markets exemplifies our position and illustrate mechanisms by which institutions influence DCs. DCs are path-dependent and primarily home-grown routines and knowledge-related operant processes (Eisenhardt \& Martin, 
2000; Eriksson, 2014). Meanwhile, institutions are more pervasive and dominant in emerging markets (Wright et al., 2005). Emerging markets are typically characterized by strong institutional influence on firm structure, activities, and performance (Hoskisson et al., 2013). Oftentimes, their societies are tighter, imposing greater sanctioning on potentially deviant and innovative firm behavior (Taras et al., 2010). Likewise, their institutions pose strong influence on how firms behave (Wright et al., 2005). For instance, Russia has a large, skilled, and well-educated pool of human capital (Algieri, 2006). However, few firms from there succeed in a global arena, due to weak institutions identified with political instability, corruption, and ineffective incentive systems (Algieri, 2006). Despite their apparent potential and capabilities, human capital stemming from individual DCs often stay dormant in such settings, due to being curbed by institutional constraints and dysfunctionalities.

Conversely, institutions can play a facilitating role to DCs by providing structure and coordinated setting, in which DCs are configured, deployed, and utilized (Ahuja \& Yayavaram, 2011). They can constitute collective social capital for entrepreneurial behavior (Bøllingtoft \& Ulhøi, 2005). The rule of law, corporate board efficacy, effective resource orchestration, liberal market entry policies, and free corporate governance mechanisms can provide a conducive setting to firms for configuring, deploying, and leveraging DCs (Hoskisson et al., 2013; Teece, 2007). For instance, American pharmaceutical firms are more innovative than their Japanese counterparts, due to higher institutional conduciveness to drug innovations in the US compared to Japan (Peng et al., 2009). American firms operate in more open and tolerant institutional settings that are favorable to diversity (Peng et al., 2009). The influence of such supportive institutions can also be witnessed in the formation of new entrepreneurial ventures, where new ventures per capita are higher in Scandinavian countries like Sweden and Denmark than other developed European economies with similar economic conditions like France or Belgium (World Atlas, 2015). Likewise, reformative institutions in South Korea allowed local firms to develop and 
leverage superior innovative capabilities and expand abroad successfully (Hoskisson et al., 2013). Furthermore, institutions can endow firms with political skills, the ability to thrive in adverse circumstances as unique DCs for their circumstances (Gammeltoft et al., 2010).

In particular, most developed economies offer notably different and often conducive institutional environment to firms and new ventures. Though institutional environments of developed economies are not homogenous (Kuznetsov \& Jacob, 2015), they are typically classified as having a positive influence of varying extent and nature (Boschma \& Capone, 2015; Hall \& Thelen, 2009). For example, while coordinated market economies are more conducive to evolutionary change, liberal market economies are more conducive to revolutionary change in industrial and firm structures (Boschma \& Capone, 2015). This finding suggests that rigorously structured institutional norms and rules and their tight enforcement have an alternating influence on the development and deployment of DCs. In contrast, liberal institutional frameworks are more conducive to the development and application of DCs that enable disruptive and unrelated change.

Generally speaking, it is well recognized that firms reflect the institutional conditions of their organizational fields and national environments (Daniels et al., 2002; Gammeltoft et al., 2010). Thus, firms in different institutional frameworks develop and utilize different capabilities shaped by their institutional frame (Dunning \& Lundan, 2010). Consequently, we construe that institutions define and provide semi-flexible structures, symbolic templates, and mechanisms of socioeconomic order in which dynamic capabilities are developed, managed, and valued.

\subsection{Dynamic capabilities influence institutions}

On the other side of the coin, institutions are not always pervasive, impervious, and rigid forces (Kuznetsov \& Jacob, 2015). They are subject to be influenced and changed (Metcalfe, 2001). Institutions are socially constructed phenomena and "worked" i.e., created, maintained, and disrupted by capable agents (Lawrence \& Suddaby, 2006; Seo \& Creed, 2002). In fact, recent studies on 
institutions focus on the agency as an influence on the structure, especially when agents are entrepreneurially orientated and capable (Greenwood \& Suddaby, 2006; Suddaby, 2010). Recent research highlights the role of firm-level creativity and institutional entrepreneurship in co-evolution with the environment (Cantwell et al., 2009). Consequently, the influence of social actors (individuals and firms) as agents of institutional change and conveyors of institutional logics is also becoming increasingly apparent (Durand, 2012).

The very nature of institutions denotes rules and norms that are commonly accepted and followed in their respective settings (DiMaggio \& Powell, 1983; North, 1990). Thus, practices, values, and beliefs have to go through institutionalization processes to turn into norms and rules and count as institutions (Beckert, 1999; Meyer \& Rowan, 1977). Given their transformative and operant nature (Teece, 2009; Winter, 2003), DCs can empower agents in shaping the underlying processes of institutionalization (including creating, altering, and reproducing institutions). Agents can employ their DCs to devise transformation of practices, values, and beliefs into institutional norms and rules, alter and deinstitutionalize existing institutions, and recreate institutions.

DCs enable firms to enact mechanisms for institutional change (Dunning \& Lundan, 2010). DCs alter the ways, which include institutional routines, a firm makes its living (Pihkala et al., 2007). Thus, the influence of DCs, given their entrepreneurial and formative attributes (Teece, 2007), often extends to business ecosystems and institutions. DCs' operant influence on intangible assets, resources, and capabilities (Winter, 2003) makes them distinctive and helps create, maintain, alter, erode, and re-create otherwise perseverant institutional frameworks (Durand, 2012). DCs can enable firms to adjust to the reality and actively shape the external selection criteria of fitness to suit their resources and strategies (Dunning \& Lundan, 2010). Institutional entrepreneurs can apply their DCs to deploy resources to create, empower, and alter their ecosystems and institutions (Augier \& Teece, 2008). 
As socioeconomic behavior requires underlying conditions and capabilities (Teece, 2007), institutional entrepreneurship is underpinned by DCs and entrepreneurial capabilities (Phillips \& Tracey, 2007; Ritvala \& Granqvist, 2009). DCs are inherently entrepreneurial (Teece, 2014). They enable firms to conduct entrepreneurial activities and change business models (Teece, 2010). The persistence of institutions depends on their aggregate welfare effects and distributive benefits as well as on continuous processes of mobilization through which the actors test the limits of the existing institutions (Hall \& Thelen, 2009). Institutional entrepreneurship is viewed as a force for both evolutionary and disruptive change in institutions (Phillips \& Tracey, 2007). In turn, entrepreneurial processes that change institutions rely on the capabilities of the actors conducting such processes (Ritvala \& Granqvist, 2009). For example, Greenwood, Suddaby, and Hinings (2002) argue that so as to overcome the inertia that characterizes mature institutions, and purposefully stimulate institutional change, institutional entrepreneurs are required to have the ability to streamline and refine the causes and consequences of dominant norms and practices, and to question their utility. In the context of emerging institutional fields, Maguire, Hardy, and Lawrence (2004) argue that institutional entrepreneurs tend to have the abilities to develop arguments that appeal to various stakeholders, make connections between existing and the new practices, and align the new practices with the values of key stakeholders.

An initial role of DCs in influencing institutions and institutional elements could be defining, coopting, and shaping institutional values and rules. At this stage, DCs enable social agents to exert microfoundational and pluralizing influence on institutional logics for evolutionary institutional change. Nevertheless, a more ample impact of DCs is revealed in erosion and (re)formation of institutions (Durand, 2012; Greenwood \& Suddaby, 2006). For instance, DCs are found to play a pivotal role in breaking socio-institutional inertia (Pihkala et al., 2007). Likewise, entrepreneurial firms' DCs enable them to be creatively destructive (destroying established taken-for-granted rules and 
re-establishing new ones) (Beckert, 1999) and envision alternative modes of getting things done in unfavorable institutional situations. Finally, DCs can reveal their influence on institutions not only with regard to changing them but also with regard to linking them to each other. Recent research suggests that entrepreneurial capabilities can span the distance between two institutional contexts, namely bridge them to tap opportunities that institutional divide present (Karra, Phillips, \& Tracey, 2008). Thus, DCs are not only influential to the agents who have access to and utilize them but also could play a pivotal role in shaping institutions as entities exogenous to such agents. In short, we posit that dynamic capabilities enable agents to effectively serve their purposes within the institutional order as well as change (create, maintain, and disrupt) and bridge institutions.

\section{Future research agenda}

The synthesis of two approaches promises to beget fruitful research avenues. When studying the research questions posed below, the synthesis recognizes that sustaining a dynamic fit between what the firm does and what the environment demands can yield superior returns. Hence, the synthesized approach could serve as a good point of departure to address the research agenda developed here and may facilitate the reconciliation of the ongoing agency vs. structure debate (Heugens \& Lander, 2009).

Insert Table 3 here

Entrepreneurial activities are results of social interactions and mechanisms and cannot solely be understood in terms of inherent characteristics and attributes or in sterile economic conditions (Ulhøi, 2005). We summarize some questions for future research that are relevant to strategic entrepreneurship research and can be addressed by adopting synthesized approach that includes key internal and external forces behind entrepreneurship in Table 3. In an effort to build an initial roadmap for future research, research possibilities concerning four key phenomena (bricolage, business model, institutional work, and entrepreneurial orientation) that could benefit from the synthesis are discussed. These four phenomena coherently cover diverse critical issues germane to strategic entrepreneurship. They are 
diverse because they are rooted in different paradigms and explain different aspects of strategic entrepreneurship. However, they also constitute a cohesive whole. Three underlying threads coherently interweave these four concepts together and justify their inclusion. First, they all connote behavioral and structural elements underlying the interface between agency (actor) and structure (environment). Second, antecedents, nature, and consequences of these concepts are distinctly intertwined with both institutions and DCs. Third, all four concepts are embedded in strategic entrepreneurship domain.

First, bricolage refers to making do with resources at hand particularly within constrained environments to solve problems and uncover opportunities (Baker \& Nelson, 2005). Bricolage is creative entrepreneurial capability and processes that undergird utilizing what is at hand (Phillips \& Tracey, 2007). It is a critical characteristic of strategic entrepreneurship (Baker \& Nelson, 2005) and a central yet insufficiently understood theme in the strategic entrepreneurship field (Welter et al., 2016). Bricolage is relevant to entrepreneurship particularly in resource-deficient institutional settings and could be viewed as a mechanism of institutional transformation (Desa, 2012). Bricolage is inextricably intertwined both with institutional fields that bricoleurs are embedded in and capabilities that are exploited for bricolage (Phillips \& Tracey, 2007). Thus, institutions are likely to influence the nature of bricolage, while DCs may act as underlying mechanisms for bricolage as a set of activities.

Researchers can shed more light on bricolage and its role in surviving and dealing with institutional voids by combining insight from IA and DCA. First, the exploration of managerial strategizing about relevant capabilities in penurious environments could advance understanding of bricolage. Likewise, scholars are encouraged to explore DCs that can enable enacting limitations and improvising in various institutional settings. As bricolage cannot occur in a vacuum, the exploration of underlying DCs that function as microfoundations to bricolage can help advance knowledge on bricolage. In short, institutions and DCs can play a pivotal and complementary role in bricolage, and the synthesized approach can enable uncovering the antecedents, nature, outcomes of bricolage. 
Second, business model concept partially draws on DCA and denotes a design or architecture of the value creation, delivery, and capture mechanisms (Teece, 2010). Business model is a structural template describing the organization of firms' transactions with external constituents including institutions (Ehret, Kashyap, \& Wirtz, 2013). Meanwhile, business model mechanisms involve DCs in the pursuit of realizing a strategy (Teece, 2010, 2014). Despite their transformative role in value creation and capture (Teece, 2010), business models are context bounded.

Despite a close courtship between research of business model and DCA (Teece, 2010), institutional underpinnings of business models have often been ignored. This popular and contested concept can better be understood if researchers account jointly for institutions and DCs underlying business models and mechanisms of their establishment, renewal, and functioning. In particular, exploring institutional underpinnings of business models and DCs identified with successful business models in different institutional fields can reveal unique insights into the concept. It is well-established in the literature that intuitions shape the mindset, values, and symbolic worlds of decision makers. Thus, IA can offer unique insights to business model research in addition to DCA. Likewise, research on business model innovation and the relationship between business models and value creation and capture can considerably benefit from the synthesized adoption of IA and DCA.

Third, institutional work, which encompasses institutional and social entrepreneurship (Desa, 2012; Garud et al., 2007) and deinstitutionalization (Maguire \& Hardy, 2009), refers to the purposive action of individuals and organizations aimed at creating, maintaining, and disrupting institutions (Lawrence \& Suddaby, 2006). Institutional work accepts agents as active entities who are conscious, skillful, and reflexive (Lawrence \& Suddaby, 2006), leading to an increasing correspondence between management theory and IA. Thus, though biased toward agency side, the concept of institutional work can help resolve structure vs. agency debate (Heugens \& Lander, 2009), and subtly signals the role of DCs, through actions of agents, in creating, maintaining, and disrupting institutions. 
As the research on institutional work remains fragmented and underdeveloped (Desa, 2012; Lawrence \& Suddaby, 2006), including DCA into the equation can uncover the means and underlying mechanisms that socioeconomic agents execute institutional work. Likewise, though the extensive body of research has accumulated on institutional entrepreneurship (Garud et al., 2007; Greenwood \& Suddaby, 2006), DCA has been somewhat missing in this conversation in spite of potentially pivotal role that DCs can play in institutional entrepreneurship. Examining the role of DCs in institutional work and institutional entrepreneurship can yield promising future research avenues. Likewise, the popular phenomena of institutional change (Seo \& Creed, 2002) and deinstitutionalization (Maguire \& Hardy, 2009) can be enlightened further with the synthesis of IA and DCA.

Fourth, referring to the disposition to accept and adopt entrepreneurial processes, practices, and decision-making activities that lead to developing new and distinctive value offerings (Lumpkin \& Dess, 1996), entrepreneurial orientation (EO) represents a sizeable research stream in strategy and entrepreneurship research. EO plays an influential role in defining the managerial mindset as well as firm scope, structure, and functioning (Lumpkin \& Dess, 1996). Since orientation itself designates the overall and enduring direction of thought, disposition, and interest, EO is instrumental in shaping how and what DCs a firm develops, applies, and leverages over time. On the other hand, because institutions affect behavior and beliefs of firms by providing templates for action, cognition, and emotion (Lawrence et al., 2011), EO can be shaped by various institutions.

IA and DCA have been scarcely applied in tandem to explore EO. EO could be reinvigorated through synthesized adoption of IA and DCA. Interesting insights into EO can be gained at the interface between institutions and DCs. Exemplary research directions drawing on this notion include but not limited to diffusion of institutional logics into EO, institutional underpinnings of EO and its relation to DCs, and the consequences of EO with regard to key DCs in various institutional fields.

\section{Discussion and conclusions}


This study makes three distinct contributions. First, through a comparative analysis of IA and DCA, the study sheds some light on the differences, intersecting dimensions, and complementarities of IA and DCA that signify correspondence commencing between the two approaches and inform the following synthesis. Second, drawing on the interaction between the two approaches, the proposed synthesis of the approaches reveals how institutions and DCs are intertwined. Thus, these approaches' synthesized adoption could result in more logically consistent and generative explanations to relevant issues in strategic entrepreneurship than their single adoption. Third, the concepts discussed in the research agenda represent a part of various issues with regard to strategic entrepreneurship where the synthesized, rather than discrete or paired, adoption of IA and DCA could reveal useful insights. The suggested synthesized approach underlines that key concepts and issues informed by both IA and DCA in a single framework can reveal unique and rich insights.

Synthesizing is not integrating two distinct theoretical approaches to arrive a new one. Given the sheer size of the body of work following the two approaches, their incompatible aspects, and premises, integrating these influential approaches into one would be a daunting task to embark upon. Instead, we argue that applying IA and DCA jointly for specific research agendas to account for the dynamic intertwinement between institutions and DCs could be both more feasible and effective for advancing the body of knowledge in a field like strategic entrepreneurship. Thus, IA's recent attention by institutional entrepreneurship to the underlying mechanisms of agency in creation, maintenance, and transformation of institutions can be enhanced via the capabilities focus of DCA. Likewise, DCA can gain more credibility and applicability if it accounts for the institutional boundary conditions that DCs are developed, conditioned, managed, and bounded (Barreto, 2010).

Drawing on the extensive body of research, we conclude that institutions, as constructed realities and mechanisms that condition and designate patterns of proper social arrangements and behaviors, represent order and define the overall, perseverant but semi-flexible frame that firms have room to 
behave and perform. In turn, DCs, representing change, allow firms to maneuver within the frame provided by institutions to obtain desired outcomes and create, embody, change, erode, or recreate the very institutional frame that firms are embedded in. Thus, the true influence of either institutional forces or DCs on related issues cannot be fully and deeply understood without accounting for the other.

An anecdotal depiction of our core argument is the example of a distinct entrepreneur Steve Jobs and Apple Inc. Had his biological father raised him in Syria, Steve Jobs would have never had opportunities provided by institutions in the US (Goodman, 2011). Institutional frame in the US provided him with a structure conducive to be innovative and sense, seize, and reconfigure given opportunities. However, after all, his entrepreneurial capabilities made a difference within the US, enabling him to capitalize on the favorable institutional frame and differentiate from others. In turn, partly due to his achievements, Apple Inc. redefined norms of its industry, playing a distinctive role in changing its institutional environment. Drawing on our analysis and this anecdote, we argue that while IA is likely to have more explanatory power on the normal behavior (or more specifically average and aggregated performance) of entrepreneurs/firms in an institutional context, DCA is likely to have more explanatory power on the nature and extent of individual deviations from such normal or average.

As the research agenda shows, strategic entrepreneurship can be a distinct beneficiary of the synthesis of IA and DCA. Among others, four relevant strategic entrepreneurship phenomena can better be understood via research following IA and DCA's synthesized adoption. All of these phenomena have important and emerging places in strategic entrepreneurship, and all demand innovative research approaches to spur the advancement of our knowledge about them. The synthesis of IA and DCA can enable researchers to have an inclusive look at these strategic entrepreneurship phenomena and achieve fuller comprehension of pertinent concepts and relationships among them.

To sum up, exclusivist "either-or" approaches to research problematization and theorization are often fallacious or incomplete (Heugens \& Lander, 2009). Theoretical approaches are not religions to 
live by. They grant researchers with a lens for explaining and predicting issues, and an educated and designated synthesis of approaches lead to better lenses. Neither parsimony nor inclusiveness needs to be sacrificed for the sake of the other when designing and conducting research. DCs can better be understood by examining the structuring of institutions in which socioeconomic entities are embedded, and institutions can better be understood by examining DCs that can enact and embody them. Synthesized adoption of IA and DCA can provide a stronger explanation to relevant issues in management field without sacrificing from parsimony. After all, this study is exploratory and aims to offer a joint perspective for strategic entrepreneurship research by synthesizing established approaches. We hope that this study will stimulate further conceptual and empirical research that draws on the core premises of ideas presented here. 


\section{References}

Acemoglu, D., Johnson, S., Robinson, J., \& Thaicharoen, Y. (2003). Institutional causes, macroeconomic symptoms: Volatility, crises and growth. Journal of Monetary Economics, 50(1), 49-123.

Ahuja, G., \& Yayavaram, S. (2011). Perspective - explaining influence rents: The case for an institutionsbased view of strategy. Organization Science, 22(6), 1631-1652.

Algieri, B. (2006). Human capital in Russia. The European Journal of Comparative Economics, 3(1), 103-129.

Alvarez, S. A., Audretsch, D., \& Link, A. N. (2016). Advancing our understanding of theory in entrepreneurship. Strategic Entrepreneurship Journal, 10(1), 3-4.

Arend, R., \& Bromiley, P. (2009). Assessing the dynamic capabilities view: Spare change, everyone? Strategic Organization, 7(1), 75-90.

Atlas, W. (2015). Retrieved 24/05/2017, from http://www.worldatlas.com/articles/countries-with-themost-opportunity-in-the-world.html

Augier, M., \& Teece, D. J. (2008). Strategy as evolution with design: The foundations of dynamic capabilities and the role of managers in the economic system. Organization Studies, 29(8-9), 1187-1208.

Baker, T., \& Nelson, R. E. (2005). Creating something from nothing: Resource construction through entrepreneurial bricolage. Administrative Science Quarterly, 50(3), 329-366.

Barreto, I. (2010). Dynamic capabilities: A review of past research and an agenda for the future. Journal of Management, 36(1), 256-280.

Beckert, J. (1999). Agency, entrepreneurs, and institutional change. The role of strategic choice and institutionalized practices in organizations. Organization Studies, 20(5), 777-799.

Berger, P. L., \& Luckmann, T. (1967). The social construction of reality: A treatise in the sociology of knowledge. New York, NY: Anchor Books.

Bøllingtoft, A., \& Ulhøi, J. P. (2005). The networked business incubator-leveraging entrepreneurial agency? Journal of Business Venturing, 20(2), 265-290.

Boschma, R., \& Capone, G. (2015). Institutions and diversification: Related versus unrelated diversification in a varieties of capitalism framework. Research Policy, 44(10), 1902-1914.

Burg, E., \& Romme, A. G. L. (2014). Creating the future together: Toward a framework for research synthesis in entrepreneurship. Entrepreneurship Theory and Practice, 38(2), 369-397.

Cantwell, J., Dunning, J. H., \& Lundan, S. M. (2009). An evolutionary approach to understanding international business activity: The co-evolution of MNEs and the institutional environment. Journal of International Business Studies, 41(4), 567-586.

Daniels, K., Johnson, G., \& de Chernatony, L. (2002). Task and institutional influences on managers' mental models of competition. Organization Studies, 23(1), 31-62.

Desa, G. (2012). Resource mobilization in international social entrepreneurship: Bricolage as a mechanism of institutional transformation. Entrepreneurship Theory and Practice, 36(4), 727 751.

DiMaggio, P., \& Powell, W. (1983). The iron cage revisited: Institutional isomorphism and collective rationality in organizational fields. American Sociological Review, 48(2), 147-160.

Dixon, S., Meyer, K., \& Day, M. (2014). Building dynamic capabilities of adaptation and innovation: A study of micro-foundations in a transition economy. Long Range Planning, 47(4), 186-205.

Dunning, J. H., \& Lundan, S. M. (2010). The institutional origins of dynamic capabilities in multinational enterprises. Industrial and corporate change, 19(4), 1225-1246.

Durand, R. (2012). Advancing strategy and organization research in concert: Towards an integrated model? Strategic Organization, 10(3), 297-303.

Ehret, M., Kashyap, V., \& Wirtz, J. (2013). Business models: Impact on business markets and opportunities for marketing research. Industrial Marketing Management, 42(5), 649-655.

Eisenhardt, K. M., \& Martin, J. A. (2000). Dynamic capabilities: What are they? Strategic Management Journal, 21(10/11), 1105-1121. 
Eriksson, T. (2014). Processes, antecedents and outcomes of dynamic capabilities. Scandinavian Journal of Management, 30(1), 65-82.

Faulconbridge, J. R., \& Muzio, D. (2015). Transnational corporations shaping institutional change: The case of English law firms in Germany. Journal of Economic Geography, 15, 1195-1126.

Gammeltoft, P., Barnard, H., \& Madhok, A. (2010). Emerging multinationals, emerging theory: Macroand micro-level perspectives. Journal of International Management, 16(2), 95-101.

Garud, R., Hardy, C., \& Maguire, S. (2007). Institutional entrepreneurship as embedded agency: An introduction to the special issue. Organization Studies, 28(7), 957-969.

Goodman, D. J. (2011). Steve Jobs, son of a Syrian, is embraced in the Arab world. The New York Times. Retrieved from http://thelede.blogs.nytimes.com/2011/10/06/steve-jobs-son-of-a-syrian-isembraced-in-the-arab-world/? $\mathrm{r}=0$

Greenwood, R., \& Suddaby, R. (2006). Institutional entrepreneurship in mature fields: The big five accounting firms. Academy of Management Journal, 49(1), 27-48.

Greenwood, R., Suddaby, R., \& Hinings, C. R. (2002). Theorizing change: The role of professional associations in the transformation of institutionalized fields. Academy of Management Journal, 45(1), 58-80.

Hall, P. A., \& Thelen, K. (2009). Institutional change in varieties of capitalism. Socio-Economic Review, 7(1), 7-34.

Hasselbladh, H., \& Kallinikos, J. (2000). The project of rationalization: A critique and reappraisal of neoinstitutionalism in organization studies. Organization Studies, 21(4), 697-720.

Helfat, C., \& Peteraf, M. (2015). Managerial cognitive capabilities and the microfoundations of dynamic capabilities. Strategic Management Journal, 36(6), 831-850.

Heugens, P. P., \& Lander, M. W. (2009). Structure! Agency!(and other quarrels): A meta-analysis of institutional theories of organization. Academy of Management Journal, 52(1), 61-85.

Hitt, M. A., Ireland, R. D., Sirmon, D. G., \& Trahms, C. A. (2011). Strategic entrepreneurship: Creating value for individuals, organizations, and society. Academy of Management Perspectives, 25(2), $57-75$.

Hoskisson, R. E., Wright, M., Filatotchev, I., \& Peng, M. W. (2013). Emerging multinationals from midrange economies: The influence of institutions and factor markets. Journal of Management Studies, 50(7), 1295-1321.

Karra, N., Phillips, N., \& Tracey, P. (2008). Building the born global firm: Developing entrepreneurial capabilities for international new venture success. Long Range Planning, 41(4), 440-458.

Katkalo, V. S., Pitelis, C. N., \& Teece, D. J. (2010). Introduction: On the nature and scope of dynamic capabilities. Industrial and corporate change, 19(4), 1175-1186.

Kiss, A. N., Danis, W. M., \& Cavusgil, S. T. (2011). International entrepreneurship research in emerging economies: A critical review and research agenda. Journal of Business Venturing.

Kostova, T., Roth, K., \& Dacin, M. T. (2008). Institutional theory in the study of multinational corporations: A critique and new directions. Academy of Management Review, 33(4), 994-1006.

Kuznetsov, A., \& Jacob, M. (2015). Institutional adjustment and change at the firm level: A varieties of capitalism perspective. Scandinavian Journal of Management, 31(2), 165-177.

Lawrence, T., \& Suddaby, R. (2006). Institutions and institutional work. In S. Clegg, C. Hardy, \& W. Nord (Eds.), The sage handbook of organization studies (pp. 215-254). London, UK: Sage Publications Ltd.

Lawrence, T., Suddaby, R., \& Leca, B. (2011). Institutional work: Refocusing institutional studies of organization. Journal of Management Inquiry, 20(1), 52-58.

Lessard, D., Teece, D. J., \& Leih, S. (2016). Introduction to special topic forum on developing the dynamic capabilities of global companies across levels and locations. Global Strategy Journal, 6(3), 165-167.

Li, Y., Xie, E., Teo, H.-H., \& Peng, M. (2010). Formal control and social control in domestic and international buyer-supplier relationships. Journal of Operations Management, 28(4), 333-344. 
Lu, Y., Zhou, L., Bruton, G., \& Li, W. (2009). Capabilities as a mediator linking resources and the international performance of entrepreneurial firms in an emerging economy. Journal of International Business Studies, 41(3), 419-436.

Lumpkin, G. T., \& Dess, G. G. (1996). Clarifying the entrepreneurial orientation construct and linking it to performance. Academy of Management Review, 21(1), 135-172.

Maguire, S., \& Hardy, C. (2009). Discourse and deinstitutionalization: The decline of DDT. Academy of Management Journal, 52(1), 148-178.

Maguire, S., Hardy, C., \& Lawrence, T. B. (2004). Institutional entrepreneurship in emerging fields: Hiv/aids treatment advocacy in Canada. Academy of Management Journal, 47(5), 657-679.

McKague, K. (2011). Dynamic capabilities of institutional entrepreneurship. Journal of Enterprising Communities: People and Places in the Global Economy, 5(1), 11-28.

Metcalfe, J. S. (2001). Institutions and progress. Industrial and corporate change, 10(3), 561-586.

Meyer, J. W., \& Rowan, B. (1977). Institutionalized organizations: Formal structure as myth and ceremony. American Journal of Sociology, 83(2), 340-363.

Michailova, S., \& Zhan, W. (2015). Dynamic capabilities and innovation in MNC subsidiaries. Journal of World Business, 50(3), 576-583.

North, D. C. (1990). Institutions, institutional change, and economic performance: Cambridge Univ Pr.

Oliver, C. (1997). Sustainable competitive advantage: Combining institutional and resource-based views. Strategic Management Journal, 18(9), 697-713.

Peng, M. W., \& Khoury, T. A. (2008). Unbundling the institution-based view of international business strategy. In A. M. Rugman (Ed.), Oxford handbook of international business (pp. 256-268). New York, NY: Oxford University Press.

Peng, M. W., Sunny, L., Brian, P., \& Hao, C. (2009). The institution-based view as a third leg for a strategy tripod. Academy of Management Perspectives, 23(3), 63-81.

Pernkopf-Konhäusner, K. (2014). The competent actor bridging institutional logics and French pragmatist sociology. Journal of Management Inquiry, 23(3), 333-337.

Phillips, N., \& Tracey, P. (2007). Opportunity recognition, entrepreneurial capabilities and bricolage: Connecting institutional theory and entrepreneurship in strategic organization. Strategic Organization, 5(3), 313-320.

Pihkala, T., Harmaakorpi, V., \& Pekkarinen, S. (2007). The role of dynamic capabilities and social capital in breaking socio-institutional inertia in regional development. International Journal of Urban and Regional Research, 31(4), 836-852.

Regnér, P., \& Edman, J. (2014). Mne institutional advantage: How subunits shape, transpose and evade host country institutions. Journal of International Business Studies, 45(3), 275-302.

Ritvala, T., \& Granqvist, N. (2009). Institutional entrepreneurs and local embedding of global scientific ideas - the case of preventing heart disease in Finland. Scandinavian Journal of Management, 25(2), 133-145.

Schriber, S. (2016). Nordic strategy research-topics, theories, and trends. Scandinavian Journal of Management, 32(4), 220-230.

Scott, W. R. (2001). Institutions and organizations (2nd ed.). Thousand Oaks, CA: Sage.

Scott, W. R. (2008). Approaching adulthood: The maturing of institutional theory. Theory and Society, $37(5), 427-442$.

Seo, M.-G., \& Creed, W. E. D. (2002). Institutional contradictions, praxis, and institutional change: A dialectical perspective. Academy of Management Review, 27(2), 222-247.

Suddaby, R. (2010). Challenges for institutional theory. Journal of Management Inquiry, 19(1), 14-20.

Taras, V., Kirkman, B. L., \& Steel, P. (2010). Examining the impact of culture's consequences: A threedecade, multilevel, meta-analytic review of Hofstede's cultural value dimensions. Journal of Applied Psychology, 95(3), 405-439.

Teece, D. J. (2007). Explicating dynamic capabilities: The nature and microfoundations of (sustainable) enterprise performance. Strategic Management Journal, 28(13), 1319-1350. 
Teece, D. J. (2009). Dynamic capabilities and strategic management: Organizing for innovation and growth. New York, NY: Oxford University Press.

Teece, D. J. (2010). Business models, business strategy and innovation. Long Range Planning, 43(2), 172-194.

Teece, D. J. (2014). A dynamic capabilities-based entrepreneurial theory of the multinational enterprise. Journal of International Business Studies, 45(1), 8-37.

Teece, D. J., Pisano, G., \& Shuen, A. (1997). Dynamic capabilities and strategic management. Strategic Management Journal, 18(7), 509-533.

Ulhøi, J. P. (2005). The social dimensions of entrepreneurship. Technovation, 25(8), 939-946.

Vogel, R., \& Güttel, W. H. (2013). The dynamic capability view in strategic management: A bibliometric review. International Journal of Management Reviews, 15(4), 426-446.

Welter, C., Mauer, R., \& Wuebker, R. J. (2016). Bridging behavioral models and theoretical concepts: Effectuation and bricolage in the opportunity creation framework. Strategic Entrepreneurship Journal, 10(1), 5-20.

Welter, F., \& Smallbone, D. (2011). Institutional perspectives on entrepreneurial behavior in challenging environments. Journal of Small Business Management, 49(1), 107-125.

Willmott, H. (2014). Why institutional theory cannot be critical. Journal of Management Inquiry.

Winter, S. G. (2003). Understanding dynamic capabilities. Strategic Management Journal, 24(10), 991995.

Wood, G., Dibben, P., \& Ogden, S. (2014). Comparative capitalism without capitalism, and production without workers: The limits and possibilities of contemporary institutional analysis. International Journal of Management Reviews, 16(4), 384-396.

Wright, M., Filatotchev, I., Hoskisson, R. E., \& Peng, M. W. (2005). Strategy research in emerging economies: Challenging the conventional wisdom. Journal of Management Studies, 42(1), 1-33.

Wu, J. (2013). Marketing capabilities, institutional development, and the performance of emerging market firms: A multinational study. International Journal of Research in Marketing, 30(1), 36-45. 
Table 1

Differences between institutional and dynamic capabilities approaches

\begin{tabular}{lll}
\hline Differences & Institutional Approach & Dynamic Capabilities Approach \\
\hline Care premise & $\begin{array}{l}\text { Institutions provide meaning and } \\
\text { structure to socioeconomic } \\
\text { behavior and cognition } \\
\text { Structure }\end{array}$ & $\begin{array}{l}\text { Dynamic capabilities can be a source } \\
\text { of competitive advantage in rapidly } \\
\text { changing environments } \\
\text { Agency }\end{array}$ \\
$\begin{array}{l}\text { What the core concepts } \\
\begin{array}{l}\text { Underlying reason for } \\
\text { following certain } \\
\text { activities and structures }\end{array}\end{array}$ & Meaning & Productive value \\
$\begin{array}{l}\text { Assumed function of } \\
\text { core concepts }\end{array}$ & Similarity/convergence \\
$\begin{array}{l}\text { Desired outcome } \\
\text { Assumed decision } \\
\text { process of focal actors }\end{array}$ & Legitimacy - survival & Differentiation/divergence \\
\hline
\end{tabular}

Table 2

Commonalities between institutional and dynamic capabilities approaches

\begin{tabular}{lc}
\hline Commonalities & Institutional Approach and Dynamic Capabilities Appraoch \\
\hline Relationships with other actors & Interconnectedness, interdependence, relatedness \\
$\begin{array}{l}\text { Formation of relevant } \\
\text { constituents }\end{array}$ & Venturing \\
Relationship with environment & Interactive \\
\hline
\end{tabular}


Table 3

Research agenda for strategic entrepreneurship

\begin{tabular}{|c|c|}
\hline Phenomenon & Potential research questions that could be answered via synthesized approach \\
\hline Bricolage & $\begin{array}{l}\text { - What dynamic capabilities enable bricolage in institutionally constraint } \\
\text { environments? } \\
\text { - How do firms overcome institutional voids via bricolage? } \\
\text { - How do firms strategize and realize their capabilities in penurious environments? } \\
\text { activities? }\end{array}$ \\
\hline Business model & $\begin{array}{l}\text { - What are the dynamic capabilities that are identified with successful business models } \\
\text { across different institutional fields and logics? } \\
\text { - How do macro institutional norms and rules and micro institutional logics influence } \\
\text { the formation and application of business models? } \\
\text { - Do institutions play a role in business model innovation and translation of business } \\
\text { models into value creation and capture? } \\
\text { - What are institutional and capability-based mechanisms that underlie firms' business } \\
\text { models? }\end{array}$ \\
\hline $\begin{array}{l}\text { Institutional } \\
\text { work }\end{array}$ & $\begin{array}{l}\text { - What is the role of dynamic capabilities in institutional entrepreneurship in emerging } \\
\text { and mature institutional fields? } \\
\text { - What dynamic capabilities do initiation, process, and aftermath of } \\
\text { deinstitutionalization involve? } \\
\text { - How do dynamic capabilities and institutions co-evolve over time through } \\
\text { institutional work? } \\
\text { What is the role of dynamic capabilities in forming, maintaining, transforming, and } \\
\text { dissolving institutional logics }\end{array}$ \\
\hline $\begin{array}{l}\text { En } \\
\text { ori }\end{array}$ & $\begin{array}{l}\text { - What institutional logics does entrepreneurial orientation convey in its characteristics } \\
\text { - How manifestation? } \\
\text { - How do role of entrepreneurial orientation in seeding, forming, and leveraging } \\
\text { - How do institutions shape the formation and manifestation of entrepreneurial } \\
\text { orientation as well as its linkage to dynamic capabilities? } \\
\text { What is the role of institutions in shaping various types of entrepreneurial orientation } \\
\text { that conveys effectuation versus causation? }\end{array}$ \\
\hline
\end{tabular}

